\title{
An evaluation of architectural structural diagram of independent kindergartens buildings*
}

\author{
Bağımsız anaokullarının mimari plan şeması ve tipolojik yapısının \\ incelenmesi
}

Zeynep Temiz ${ }^{1}$

\begin{abstract}
This study equipped with the purpose of investigating problems originated from architectural structural diagram in independent kindergartens. Fourteen Independent Pre-school principals working in Van- Turkey participated in this study. All of them were asked to draw a sketch showing shortcoming of their schools in terms of architectural structural diagram. They were also asked to suggest amendment on their school's structural scheme to make school building more efficient to meet young children's and staffs' needs. To collect data all of the principals were given A3 size papers. Some of the principals draw their schools' sketch some of them add their schools' structural plan and make changes and take notes on those plans. After collecting all sketches document analysis was utilized for the current study. Findings of this study revealed that principals have been experiencing several problems because of structure of school buildings. All of the principals working in star-building type kindergarten declared that this school type is not appropriate for eastern region and it has many drawbacks to efficiently educate young children. The main themes emerged from this study are heating, access of children with special needs, storage and space problems.
\end{abstract}

Keywords: Independent kindergartens, school buildings, architectural structure diagram

Öz: Bu çalışmanın amacı bağımsız anaokullarının mimari plan şeması ve tipolojik yapısından kaynaklanan sorunları araştırmaktır. Çalışmaya Van ilinde görev yapmakta olan on dört bağımsız anaokulu müdürü katılmıştır. Bütün müdürlerden okullarının mimari plan şeması ve tipolojik yapısından kaynaklanan sorunları gösteren bir kroki çizmeleri istenmiştir. Ayrıca çocukların ve çalışanların ihtiyaçlarını daha iyi karşılayabilmesi için okul binasının yapısında değişiklik önerileri yapmaları istenmiş̧tir. Müdürlerin tamamı 'ylldız tipi bina' olarak adlandırılan okullarda görev yapmaktadır. Veri toplama sürecine standart getirmek için bütün müdürlere A3 kağıdı verilmiştir. Müdürlerden bazıları kendi okul krokilerini çizerken bazıları okul binasının krokisini ekleyip onun üzerinde değişiklik yapmışlardır. Bütün krokiler toplandıktan sonra doküman analizi yapılmıştır. Çalışmanın bulguları göstermiştir ki okul müdürleri binaların mimari yapısından dolayı pek çok sorun yaşamaktadırlar. Yıldız tipi okullarda görev yapan müdürlerin hepsi bu okul binasının doğu bölgelerine uygun olmadığını ayrıca küçük çocuklara etkili bir şekilde eğitim vermek için pek çok eksiği olduğunu belirtmişlerdir. Bu çalışmada ortaya çıkan temel temalar ısınma, özel gereksinimi olan çocukların okula erişimi ve depolama sorunlarıdır.

Anahtar kelimeler: Bağımsız anaokulları, okul binaları, mimari plan şeması ve tipolojik yapı

\footnotetext{
${ }^{*}$ Part of this paper was presented European Conference of Educational Research (ECER) at Budapest in 2015.

${ }^{1}$ Yüzüncü Yıl Üniversitesi, Eğitim Fakültesi, Temel Eğitim Bölümü, zakdag@yyu.edu.tr
} 


\section{INTRODUCTION}

It has been long known that the physical environment in education building plays a part in shaping children's behavior. Children not only interact with people around them they also interact with the physical environment that surround them in their daily life (Maxwell, 2007). Children are more inclined to establish an emotional bond with the space than adults. They use their sense intensely to live objects and places throughout their bodies by giving a meaning to the smells, sounds, visual images (Scoditti, Clavica, \& Caroli, 2011). Even in Reggio Emilia approach the environment is seen as 'the third educator'. In order to fulfill its educator role, the environment needs to be flexible, responsive to children and teachers' needs, help to construct children's knowledge. Environment is not a passive element rather it is an element that conditioned and is conditioned by the actions of children and adults who are active in it. Smart environment provides changes, offers choices, and promotes effective social interaction. In short, well designed environment contributes to a sense of well-being and safety for children. Malaguzzi further stated that environment is a kind of aquarium that reflects the ideas, values, attitudes and cultures of the people who lives in it (Edwards, Gandini, \& Forman, 1998).

Pre-school education has both short and long term positive effects on children and society since early childhood development is viewed as a key to social development. The quality of the physical and social environment plays a pivotal role to contribute child development in this process (Şahin \& Türkün-Dostoğlu, 2012). While designing a kindergarten various sociophilosophical and pedagogical theories is taken account of consideration. However, architectural theories must follow certain restrictive regulatory requirements, ethical and social criteria (Scoditti, Clavica, \& Caroli, 2011). There have been ongoing debates about the optimal structural quality of schools and its contribution to supporting student achievement. It is obvious that the quality of the physical environment significantly affects student achievement. Schools should be designed to be attractive and desirable to students. In doing so a space could be created that children willingly want to go. Desirable designs foster sense of belonging with particular attention to location, building materials, size of classrooms, furniture, lighting, temperature, ventilation, noise level, sanitation, and the inclusion of facilities such as library, laboratory and yard. Being functional is important for school building but it should also be friendly, welcoming and comfortable for students since schools and classrooms are more than a place to stay they can also acquire an emotional bond by children (Aydoğan, 2012). Likewise, students having education in school buildings with good architectural features develop positive feelings about their schools whereas students in school buildings with poor architectural 
features develop negative feelings about their schools. When they asked to produce metaphor about their schools participants in schools with good architectural features mostly produced metaphors under positive themes whereas participants in schools with poor architectural features produced metaphors under negative themes. In this sense, the significant improvements in the achievement of students were attributed to the general appearance of a school and the comport of the physical environment (Karasolak \& Sarı, 2011).

The main regulatory requirements includes legislation on school-building, workplace safety, sanitation and health environments, the reduction of energy consumption, and the integration of disabled people. The main social and ethical criteria includes paying attention to developmental characteristics of children and their sensory, perceptual, motor, linguistic and intellectual abilities. Natural and ecological materials are used to support both healthy growth of children and their awareness on environmental issues in the perspective of sustainable development. Kindergarten's spaces and environment should be designed to enhance intuition, imagination and creativity of the children along with development of their aesthetic and scientific thoughts. Kindergartens should also be designed in an integrated way to welcome families as well as including public spaces that foster a sense of community (Scoditti, Clavica, \& Caroli, 2011). In developing countries like Turkey the main criteria to design a kindergarten is most about financial issue. As such, when MONE tried to increase schooling rate of preschool education with several infrastructure problems it chooses to most economical way.

There has not been a long tradition of pre-school education in Turkey due to historical, economic and cultural background. Schooling rate used to be $10 \%$ around in 90 s. Until $90 \mathrm{~s}$ there has not been a recognizable effort to increase schooling rate of pre-school education. 14th National Education Council offered a course of action to increase both the schooling rate and quality of early education in 1993 (MEB, 1993). Turkish educational system experienced several attempts to solve educational problems before fulling fundamental infrastructure requirements. The situation was same when Ministry decided to increase schooling rate of preschool education. In order to increase schooling rate of pre-school education MoNE started to adapt primary education classes to nursery classes. MoNE also initiated to build independent kindergartens in all over the country.

After many attempts of Ministry of National Education (MoNE) and non-governmental organizations schooling rate increased $33 \%$ for $3-5$ years old children, $42 \%$ for $4-5$ years old children and 55\% for 5 years old children in 2016 (MoNE, 2016). Currently, Ministry of National Education is the governing body of pre-school education in Turkey and pre-school 
education is mostly offered in these two types of public schools: Independent kindergartens and nursery classes in primary school. The former have their own separate building and garden, yet the latter is only a classroom in primary schools in which first to eight grades are trained.

Table 1: Number of children and teachers in independent kindergartens and nursery classes in 20152016 academic years

\begin{tabular}{llll}
\hline & Number of schools & Number of students & Number of teacher \\
\hline Independent kindergartens & 2326 & 305.278 & 15791 \\
Nursery classes & 20061 & 682.012 & 36652 \\
\hline
\end{tabular}

Table 1 represented the number of children enrolled in Independent kindergartens and nursery classes. When the number of children educated in public school is considered, it is observed that the biggest portion belongs to nursery classes located in the scope of primary schools. In overcrowded primary schools, children at the age of preschool education are restricted with only one classroom; even a playground area that should be designed specifically for that age group cannot be divided in the school yard. As such these schools are criticized by educators for not meeting the requirements of children at that age group (Şahin \& Dostoğlu, 2014). The other public schools that offer preschool education are independent kindergartens. Structural conditions and garden opportunities are relatively better in independent kindergartens compared to nursery classes established under primary schools. Children are educated in structures that have separate yard including equipment supporting children's development. Not all the independent kindergartens are specifically designed for preschool education as existing buildings sometimes are converted to schools. Some of the Independent kindergartens also have additional facility rooms such as painting, cinema and chess rooms. Yet, some of those schools do not have any extra space for other activities other than the classroom. It is observed that there are differences among schools in terms of class dimensions, school design and its yard size. It is anticipated that it is not likely to leave this system in near future in Turkey (Şahin \& Dostoğlu, 2014). In addition to structural qualities independent kindergartens ensure better educational environment for young children as they are ruled by principals who have pre-school education background. They generally have 5 classes thus maintaining both curricular and caring tasks are much easier in comparison with nursery classes in primary schools. Some of the primary schools have more than two thousand students hence nursery classes might be neglected in those schools (Akdağ, 2012).

MoNE generally have two independent pre-school education building projects and construct same school building all over the country. Yet, independent schools have their own problems 
and the current study focused on problems originated from architectural structure. The subject of improving physical condition that can respond to the needs of young children requires us to get principals ideas since they are responsible of everything about schools. They have to carry out all paperwork, manage budget, deal with structural problems including heating, lighting, recondition, and cleaning. For this reason it is believed that principals would provide the most comprehensive information about physical environment of pre-schools, so that designers can try to reach best design solutions. This study seeks to answer following questions:

1) What is the biggest problem about Physical condition in independent schools?

2) How principals solve those problems?

3) What is the principals suggestions for improving structural quality of school building considering the culture, climate and SES of region they lived in?

\section{METHODOLOGY}

Before starting data collection researcher took official permission from Ministry of National Education. There are 25 independent pre-schools in Van. To reach principals researcher called or visited all of the 25 schools in Van and she explained the purpose of the study and asked for collaboration. Researcher could not reach three principals, two of them refused to join this study as they were out of town for business trip, three of them joined this study but researcher removed them from data log as their school building was not a star building type, finally three were located in unsafe neighborhood so researcher removed those schools' principals from participant list. Finally, researcher reached fourteen independent pre-school principals, all of whom were working in same school building typewhich is called as 'star building'. Star building is the most common independent school type in Turkey since it has a quite simple plan to construct. Star building is single-storey with 5 classes, 1 principaland 1 assistant principal room, a kitchen, a dining hall, a girl restroom, a boy restroom, personal restrooms, boiler room, and entrance hall. There is also play room but it functions more like a big corridor because all five classes get open to this play room. Star building schools is 550 square $\mathrm{m} 2$ and it is originally designed for 100 children. Yet, as it is seen at table 2 more than 100 children enrolled in participating schools. In order to increase schooling rate of pre-school education all pre-schools offer morning and afternoon classes. In this way schools capacity is two folded. Figure I showed Star Building plan. 


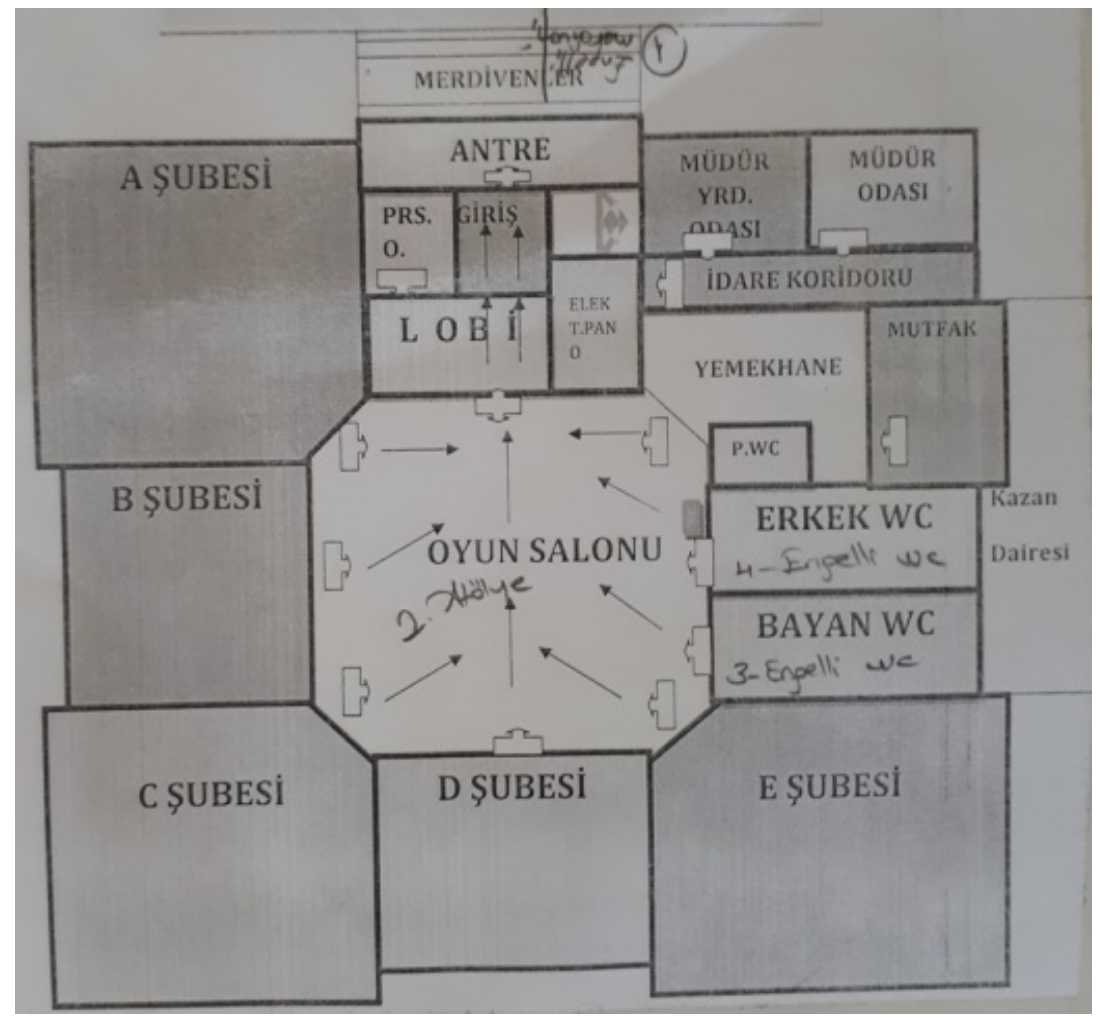

Figure 1. Star Building plan

Fourteen principals were asked to draw a sketch showing shortcoming of their schools in terms of architectural structure diagram. They were also asked to suggest amendment on their school's structure to make school building more efficient to meet young children's and staffs' needs. Table 2 represents participant characteristics.

Table 2. Participant characteristics

\begin{tabular}{lccccccc}
\hline Principals & $\begin{array}{c}\text { Years } \\
\text { of } \\
\text { Experience }\end{array}$ & $\begin{array}{c}\text { Number } \\
\text { of } \\
\text { Teachers }\end{array}$ & $\begin{array}{c}\text { Number } \\
\text { of } \\
\text { Students }\end{array}$ & Principals & $\begin{array}{c}\text { Years } \\
\text { of } \\
\text { Experience }\end{array}$ & $\begin{array}{c}\text { Number } \\
\text { of } \\
\text { Teachers }\end{array}$ & $\begin{array}{c}\text { Number } \\
\text { of } \\
\text { Students }\end{array}$ \\
\hline P1 & 10 & 8 & 157 & P8 & 4 & 5 & 112 \\
P2 & 14 & 8 & 170 & P9 & 11 & 7 & 132 \\
P3 & 8 & 5 & 94 & P10 & 6 & 6 & 140 \\
P4 & 12 & 7 & 120 & P11 & 7 & 4 & 96 \\
P5 & 12 & 5 & 124 & P12 & 13 & 8 & 165 \\
P6 & 14 & 8 & 152 & P13 & 15 & 7 & 130 \\
P7 & 9 & 6 & 117 & P14 & 6 & 8 & 166 \\
\hline
\end{tabular}

In order to set standards for data collection all the principles were given A3 size papers. Some of the principles draw their schools' sketch some of them add their schools' structural plan and make changes and take notes on those plans. Although it was not in the scope of this study principals add their comments on ideal school buildings. After collecting all sketches document analysis was utilized for the current study. It is "a technique that enables researchers to study human behavior in an indirect way through analysis of their communication" (Fraenkel \&Wallen, 2006, p.483). Open coding was used because there are no existing codes both in 
national and international literature about independent kindergartens' structural quality. Researcher first read all the documents several times. Then she created tentative labels for pieces of data. Open coding is not based on existing theory rather it is based on the meaning that emerges from data. And then, categories and themes were formed to reflect essence of the study. Coding details is seen in Table 3.

Table 3. Coding themes and categories

\begin{tabular}{|c|c|c|}
\hline Themes & Categories & Codes \\
\hline \multirow{2}{*}{ Heating } & Harsh climate & $\begin{array}{l}\text { Wrong facade } \\
\text { Boiler room problems }\end{array}$ \\
\hline & Lack of isolation & Loss of heat \\
\hline $\begin{array}{l}\text { Access of children with } \\
\text { special needs }\end{array}$ & Lack of stairs or elavators & Lack of attainment of disabled children \\
\hline \multirow{3}{*}{$\begin{array}{l}\text { Space and Storage } \\
\text { problems }\end{array}$} & Lack of disabled restrooms & Disregarding disabled children's need \\
\hline & For staff & $\begin{array}{l}\text { Unisex restrooms in dining hall } \\
\text { Lack of store for stationery materials } \\
\text { Lack of teachers' lounge }\end{array}$ \\
\hline & For children & $\begin{array}{l}\text { Lack of play areas } \\
\text { Lack of atelier } \\
\text { Lack of safe floor } \\
\text { Lack of spacious classes }\end{array}$ \\
\hline
\end{tabular}

The researcher asked a senior pre-service pre-school education teacher to code the data to ensure the inter coder reliability. Two coders openly coded the principals' sketches. Then, they compared their codes to see the commonalities and differences between their codes. The agreement on codes was quite low, which was about $62 \%$ as calculated by the following formula:

Reliability of coding: Number of coding

$$
\text { Total number of segments coded }
$$

Low agreement was originated from giving different names to the same codes. After discussing the meaning of the codes, two coders reached total agreement.

\section{FINDINGS}

Findings of this study revealed that principles have been experiencing several problems because of architectural structure diagram of school buildings. All of the principals working in starbuilding type kindergarten declared that this school type is not appropriate for this region and it has many drawbacks to efficiently educate young children. MoNE insists using same star 
building project school for years without reviewing and modifying project plans. The main themes emerged from this study are heating, access of children with special needs, storage and space problems.

\section{Heating}

There is a dramatic climate change between the coastal areas of Turkey and eastern part of Turkey where snow may lie on the ground for months and temperature might drop $-20^{\circ} \mathrm{C}$ degree (DMG, 2015). Still MONE apply sole school structure project all over the country Van's altitude is $1725 \mathrm{~m}$ thus winter is long and harsh in this region (VOG, 2015). All of the principals struggled with heating school building. Isolating buildings is not common in Turkey and school buildings are not an exception. None of the school has quality isolation, thus heating school is the biggest problem of school principals. Central heating system is working with coal and boiling room is in the basement floor and there is no place to stock up coal. All these problems result in inconvenience in principals' life. Another reason of heating loss originated from common room as there is no heater in common room. Besides common room has higher ceiling with no isolated roof.

Van ranked second in Turkey for receiving sunshine; however, misplacement of school building facade hinders schools benefit from sun. When MoNE decides to build a school it issues invitations for tender and the companies giving lowest bid win the tender. Companies who win the tender sometimes compromise on quality in order to make more profit. All of the principals complained about position of school as school entrance located on north. Thus, school entrance is become dangerous for children due to icing on long winter time. Principal 3 explained this situation:

'Company built this school's front elevation to north. Thus this school could not benefit from sunshine. Sewage pipes are closer from north so company built this school looking on north to cut back length of pipes'.

\section{Access of children with special needs}

Another problem in school structure is that there is no elevator or stairs for children with special needs although pre-school education curriculum emphasizes importance of including children with special needs into pre-school education. In addition to stairs there is no restroom for children with special needs in none of the schools. In figure 2 lacks of stairs for children with special needs is demonstrated. A column seen in figure 2 may cause injury of children. 


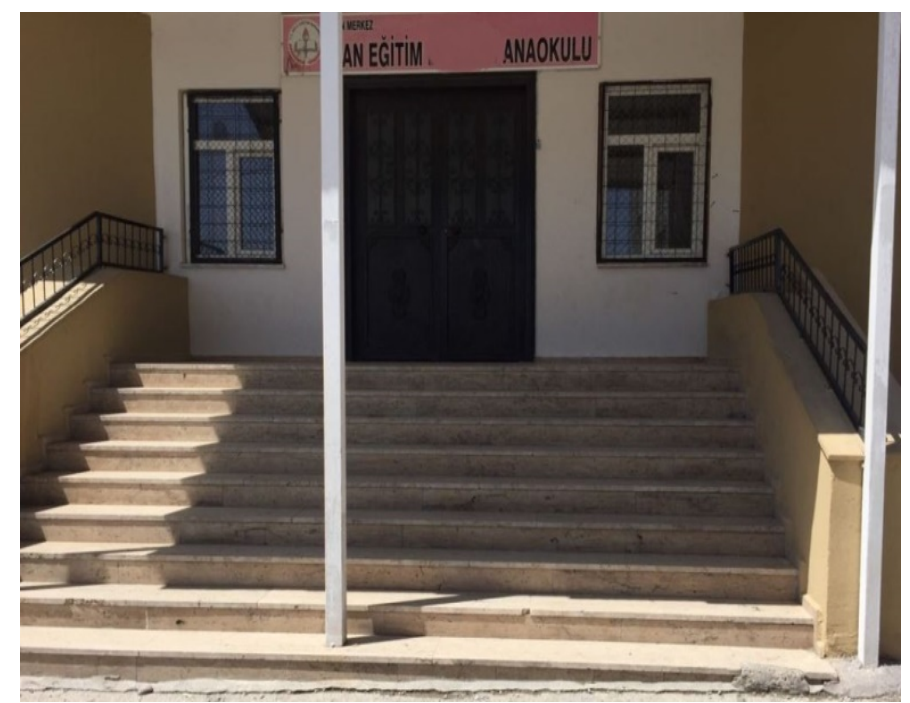

Figure 2. Star building school entrance without disabled stairs

\section{Space and Storage problems}

All of the principals and 15 vice principals out of 17 were male in this study. Six male teachers were working in those 17 schools. There is only one restroom in star building schools and all of the staffs are using same restroom. Location of restroom is also problematic as restroom is in the lunch hall.

Pre-school children do not read or write hence they could not use written materials. For this reason, pre-school education teachers needed more materials than upper grade teachers and education should be carried out with visual equipment, several toys and art materials. Principals are also in trouble to store all those materials in school since there is no storage in star-building schools. In figure 4 principal 10 addressed dimension of storage in his sketch. Based on his sketch storage size should be bigger than a class in school.

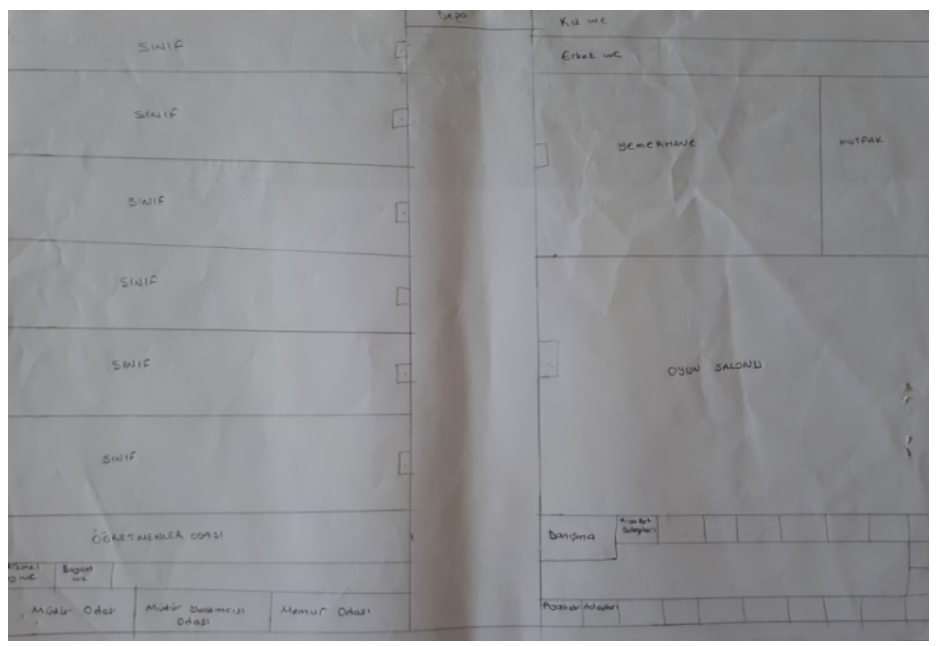

Figure 3. Need of store in school 
Lack of play areas, atelier, friendly and welcoming school entrance, teachers' lounge, safe floor, supervised private places for children, spacious classes are additional problems in independent kindergartens' architectural structure diagram.

\section{DISCUSSION and CONCULUSION}

Findings of this study suggest that in all these seventeen schools with similar architectural features there are many functional shortcomings in terms of suitability of the buildings. In order for the schools to be peaceful, trustworthy and to increase the motivation to work actions should be taken to arrange schools to meet the basic needs of children, staffs and parents. For instance as Maslow indicated people are motivated to achieve certain needs and that some needs have priority than others. Our most basic need is for physical survival needs including air, food, drink, shelter and warmth (Maslow, 1954). Unfortunately, schools fail to provide warm environment to children and staffs in school. One of the reasons of cold school building is schools' orientation to sun. The proper orientation of school buildings aim primarily to maximize benefiting from direct sunlight inside the school. The solar path is the major factors to be considered in the orientation of a school building. The Solar Path refers to the direction of the sunlight as the earth rotates on its axis which is usually from east to west. As such, MoNE suggests locating school facing the east (MoNE, 2013) yet in this study 10 school out of 17 is facing north. It is pivotal to construct school building facing east especially in eastern part of Turkey where winter is long and harsh. Ministry should control orientation of school before they are constructed. Considering the fact that one of the major problem of principals is heating the school constructing school taking school orientation to sun into account gains importance. Unfortunately there is nothing else to do for the school in this study. Yet heating problem could be solved insulating school buildings. It will also help school for energy saving.

Although MoNE has been trying to involve pre-school education into mandatory education it is still optional. Unfortunately great majority of children in Van could not benefit from early education. In this context chance of children with special needs is not high enough. When we consider inappropriate building, likelihood of children with special needs' attainment gets lower. For this reason necessary adjustment should be implemented for those children since several studies have been suggesting that children with special needs can benefit from inclusive preschool setting as they get chance to observe more complex behavior of their typically developed peers (Buysse, Goldman, \& Skinner, 2002).

It is understood that constructing same school building design all over the country could not meet the needs of all the conditions. This may cause many new school building designs to be 
emerged (Aydoğan, 2012). Some of the problems that create inconvenience in pre-school education could be removed with minor intervention but some of them could not be solved by no means like school orientation to sun. As such, ministry should carefully monitor school building tender contracts whether all articles are fulfilled or not.

\section{REFERENCES}

Aydoğan, İ. (2012). Okul binalarının özellikleri ve öğrenciler üzerine etkileri. Milli Eğitim Dergisi, 193, 29-43.

Buysse, V., Goldman, B. D., \& Skinner, M. L. (2002). Setting effects on friendship formation among young children with and without disabilities. Exceptional Children, 68(4), 503517.

Çevre ve Orman Bakanlığg Devlet Meteoroloji İşleri Genel Müdürlüğü (2015). Klimatoloji-II. Retrieved January, 10, 2015, from http://www.mgm.gov.tr/FILES/iklim/klimatoloji2.pdf

Edwards, C., Gandini, L., Forman, G. (1998). The Hundred Languages of Children: The Reggio Emilia Approach (2nd edt.). Ablex Publishing: London

Frankel, J., \& Wallen, N. (2006). How to design and evaluate research in education. Boston, MA: McGraw-Hill Higher Education.

Karasolak, K., \& Sari, M. (2011). Mimari özellikleri farkli okullardaki öğrenci ve öğretmenlerin okullarinin binasi hakkindaki görüşlerinin incelenmesi. Cukurova University Faculty of Education Journal, 40(3), 131-154.

Maslow, A. H. (1954). Motivation and personality. New York: Harper and Row.

Ministry of National Education Statistics (2016). Retrieved July, 11, 2017, from http://sgb.meb.gov.tr/meb_iys_dosyalar/2016_03/30044345 meb_istatistikleri_orgun egitim_2015_2016.pdf

Ministry of National Education (2013). Erken çocukluk eğitim kurumlarını fiziksel yapısı ve personel. $\quad$ Retrieved May, 20, 2017, from http://ismek.ist/files/ismekOrg/file/2014_hbo_program_modulleri/Erken\%20\%C3\%87 ocukluk\%20E\%C4\%9Fitim\%20Kurumlar\%C4\%B1nda\%20Fiziksel\%20\%C3\%96zelli kler\%20ve\%20Personel.pdf

Scoditti, S., Clavica, F., \& Caroli, M. (2011). Review of architecture and interior designs in Italian kindergartens and their relationship with motor development. International journal of pediatric obesity, 6(S2), 16-21.

Sahin, B., \& Dostoglu, N. (2014). Evaluation of Kindergarten Group Rooms in the Context of Size: Children and Teacher's Perspective in Turkey. European Journal of Contemporary Education, 10(4), 253-264.

Şahin, B. E., \& Türkün-Dostoğlu, N. (2012). The importance of preschoolers' experiences in kindergarten design. METU Journal of the Faculty of Architecture, 29 (1), 302-320.

Van Office of Governor (2015). Geography. Retrieved January, 10, 2015, from http://www.van.gov.tr/index.php?icerik=146\&goster=146 